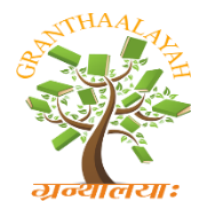
INTERNATIONAL JOURNAL OF RESEARCH
GRANTHAALAYAH
A knowledge Repository

Science

\title{
RELATIONSHIP BETWEEN PESTICIDE EXPOSURE AND HEMOGLOBIN LEVEL AND ERYTHROCYTE AMOUNT IN HORTICULTURAL FARMERS IN THE DISTRICT OF PAAL MERAH, JAMBI CITY
}

\author{
Nurhikmah ${ }^{1}$, Onny Setiani ${ }^{2}$, Yusniar H Darundiati ${ }^{3}$ \\ ${ }^{1}$ Public Health Study Program \\ ${ }^{2}$ Faculty of Public Health, Diponegoro University Semarang
}

\begin{abstract}
Background: The District of Paal Merah, Jambi City, is a center for vegetable production for the Jambi City area and its surroundings. The aspect of excessive use of pesticides by farmers in the District of Paal Merah, Jambi City is a problem that needs attention, especially the practice of spraying which ignores aspects of safety and health of farmers that can lead to health problems both directly and indirectly for farmers. One of the long-term effects caused by exposure to pesticides is a decrease in hemoglobin levels and the amount of erythrocytes in the blood. Based on the report of the Payo Selincah Health Center in Jambi City, it was explained that in the District of Paal Merah, Jambi City in 2016 showed anemia sufferers reached 30\% of the number of public health center visits.

Objective: The purpose of this study was to describe and analyze the relationship of exposure to pesticides with hemoglobin levels and the number of erythrocytes in horticultural farmers in the District of Paal Merah, Jambi City.

Method: This type of research is observational analytic with cross sectional study design conducted in the District of Red Paal with 80 respondents selected by purposive sampling. Data collection through interviews, observation, measurement of cholinesterase levels, measurement of hemoglobin levels and measurement of the amount of erythrocytes in the blood. Data analysis using chi-square test and logistic regression.

Results: Based on the results of bivariate analysis, it was found that there were 3 independent variables related to hemoglobin levels, namely work period ( $\mathrm{p}$ value $=0.005$ ), frequency of spraying $(\mathrm{p}$ value $=0.007)$, pesticide dose $(\mathrm{p}$ value $=0.003$, and no independent variables related to the number of erythrocytes.

Conclusion: Based on research from 80 farmers who examined hemoglobin levels in the blood there were $73.8 \%$ of farmers who experienced abnormal hemoglobin levels, and $26.3 \%$ of farmers who experienced normal hemoglobin levels, and from 80 farmers who examined the amount of erythrocytes in blood is $22.5 \%$ of farmers who have an abnormal number of erythrocytes, and $77.5 \%$ of farmers have normal erythrocyte counts.
\end{abstract}

Keywords: Pesticide Exposure; Hemoglobin Level; Erythrocyte Count. 
Cite This Article: Nurhikmah, Onny Setiani, and Yusniar H Darundiati. (2018). "RELATIONSHIP BETWEEN PESTICIDE EXPOSURE AND HEMOGLOBIN LEVEL AND ERYTHROCYTE AMOUNT IN HORTICULTURAL FARMERS IN THE DISTRICT OF PAAL MERAH, JAMBI CITY.” International Journal of Research - Granthaalayah, 6(11), 246-253. https://doi.org/10.29121/granthaalayah.v6.i11.2018.1122.

\section{Introduction}

Pesticides are one of the products of modern technology that have proven to play a role in improving human welfare. The use of pesticides has managed to control certain infectious disease vectors, so as to reduce the prevalence of diseases such as malaria, schistosomiasis, filariasis, dengue and bubonic plague. In agriculture, the use of pesticides can protect farmers from postharvest losses which then increase the productivity of agricultural land. The farmers consider pesticides as drugs that are able to provide increased agricultural yields, so that more pesticides are used by farmers (Zamahsjari, 1994; Siswanto, 1991)

The use of pesticides for a long time can result in exposure to pesticides in humans. Pesticides can enter the human body through the respiratory tract, digestive tract and through the skin. Pesticide poisoning can occur due to inhalation of toxic gases, contact with the skin or consuming food and beverages contaminated with pesticides (Proverawati, 2011; Kusno, 1989). Chronic poisoning in the blood profile is due to the high sulfur content in pesticides which gives rise to sulfhemoglobin bonds. This causes hemoglobin $(\mathrm{Hb})$ to become abnormal and cannot function in delivering oxygen in the blood. Sulfhemoglobin as another form of sulfur atom that binds to hemoglobin. The incidence of decreased hemoglobin levels in the blood is often experienced by patients with organophosphate and carbamate type poisoning. This is due to the formation of erythrocytes in the form of sulfhemoglobin and methemoglobin which causes a decrease in hemoglobin in the blood (Proverawati, 2011; Sofro, 2012)

Pesticide exposure to farmers can result in a decrease in hemoglobin levels in the blood. Research conducted by Sosan and Akingbohungbe in 2010 in southwest Nigeria showed results from 76 cocoa farmers there was a significant decrease in blood hemoglobin levels (Sosan, 2010). Then in Del Prado's 2007 study of measuring hemoglobin levels in 102 flower farmers using pesticides in La Trinidad, Benguet showed abnormal hemoglobin levels which were outside the range 12-18 g / dL of $15.7 \%(\mathrm{n}=16)$. Patil Jyots in a study of grape farmers who were exposed to pesticides found a decrease in several hematological components such as hemoglobin, hematocrit and Red Blood Cell (Patil, 2003; DPR I, 2013).

The Jambi City Food Security and Counseling Agency in 2016 explained that in Jambi City there were 4,514 people working in agriculture. The agricultural area is spread in almost all sub-districts in Jambi City. One of them is the District of Red Paal which is located in the south of Jambi City with an area of $280.05 \mathrm{Km} 2$ and an average height of 12 meters above sea level, consisting of 9 urban villages which are one of the sub-districts that have potential in agriculture in Jambi City. Agricultural commodities carried out by the community in the District of Red Paal, namely the types of vegetable crops including chili, mustard greens, tomatoes, spinach, basil, kale and long beans. 
Subdistrict Annual report Payo Selincah Community Health Center in Jambi City explained that its working area included the District of Paal Merah, Jambi City, and in 2016 showed anemia was often a public complaint. The number of outpatient visits that suffer from anemia reaches $30 \%$ of the number of patient visits at the community health center (Kusno, 1989).

The use of pesticides in agricultural areas in the District of Red Paal aims to control and eradicate pests, while the types of pesticides most widely used in the agricultural region are Organophosphate, Carbamat, and Organochlorin groups such as Diazinon, Curacron, Dursban, Lannate, and Tamacron.

Based on the initial survey conducted on 15 farmers in the Paal Merah sub-district of Jambi City by measuring $\mathrm{Hb}$ levels in the blood it was found that out of 15 farmers who measured Hb levels there were 8 people (53\%) who had abnormal Hb levels, while 7 people farmers (47\%) had normal $\mathrm{Hb}$ levels. In addition, based on interviews conducted with farmers, information was obtained on the implementation of pesticide spraying carried out every month with the frequency of spraying 2 to 3 times each week. In spraying activities farmers did not use complete PPE such as not wearing a mask, not using long sleeves and not using goggles. Observations were also found in some farmers who ate and smoked in agricultural areas and during spraying activities. Based on the description, the authors wished to conduct a study on the relationship of exposure to pesticides with hemoglobin levels and the number of erythrocytes in horticultural farmers in the District of Paal Merah, Jambi City.

\section{Method}

This study was an analytic observational study with a cross sectional design (cross section). The dependent variable in this study is the hemoglobin level and the number of erythrocytes, the independent variables are working period, frequency of spraying, pesticide dose. The population is all farmers who carry out pesticide spraying activities in the District of Paal Merah, Jambi City. The sample in this study were 80 people taken by purposive sampling technique. By using inclusion criteria, namely farmers involved in pesticide spraying activities, and farmers who are male sex, while the exclusion criteria are farmers who are not present at the time of inspection, farmers who have a history of serious illness (leukemia, talashemia, etc.). Data collection through interviews, observations, laboratory tests with blood sampling to measure hemoglobin levels, erythrocyte counts and examination of cholinesterase levels. Data analysis using chi square test and logistic regression.

This study has been declared to meet ethical requirements by the Health Research Ethics Commission of the Faculty of Public Health, University of Diponegoro Semarang with a description of ethical eligibility No.060 / EC / FKM / 2017.

\section{Result}

\section{Description of Research Variables}

Based on the results of the study it was known that the distribution of age of respondents ranged from 35-45 years, with the average age of respondents being 38 years. The minimum value is 35 
years and the maximum value is 67 years with a standard deviation value of 7.054 years. Most of the education of respondents was graduated from high school as many as 20 people (25\%).

The results of the study in table 1 show that the majority of respondents have a working period of $>$ 5 years, as many as 67 people (83.8\%). Respondents who had spraying frequency $>2$ times / week were 57 people $(71.3 \%)$. Respondents mostly used pesticides not according to the dosage stated on the label, which was 39 people $(48.8 \%)$.

Based on the results of laboratory examinations in Table 1, it shows that of the total 80 respondents, the majority of farmers had abnormal hemoglobin levels of 59 people $(78.8 \%)$ while those with normal hemoglobin levels were 21 people $(26.3 \%)$. In addition, the results of laboratory tests on the number of erythrocytes were known from a total of 8 farmer respondents as many as 6 people.

Table 1: Distribution of Respondents by Period of Service, Frequency of Spraying, Dosage of Pesticides, Hemoglobin Levels and Amount of Erythrocytes

\begin{tabular}{|c|c|c|c|}
\hline No & Variable & $n=80$ & $\%$ \\
\hline 1. & $\begin{array}{l}\text { Hemoglobin levels } \\
\text { a. Abnormal } \\
\text { b. normal }\end{array}$ & $\begin{array}{l}59 \\
21\end{array}$ & $\begin{array}{l}73,8 \\
26,3\end{array}$ \\
\hline 2. & $\begin{array}{l}\text { Number of erythrocytes } \\
\text { a. abnormal } \\
\text { b. normal }\end{array}$ & $\begin{array}{l}18 \\
62 \\
\end{array}$ & $\begin{array}{l}22,5 \\
77,5\end{array}$ \\
\hline 3. & $\begin{array}{l}\text { Years of service } \\
\text { a. }>5 \text { years } \\
\text { b. } \leq 5 \text { years }\end{array}$ & $\begin{array}{l}67 \\
13 \\
\end{array}$ & $\begin{array}{l}83,8 \\
16,3 \\
\end{array}$ \\
\hline 4. & $\begin{array}{l}\text { Frequency of spraying } \\
\text { a. }>2 \text { times / week } \\
\text { b. } \leq 2 \text { times / week }\end{array}$ & $\begin{array}{l}57 \\
23\end{array}$ & $\begin{array}{l}71,3 \\
28,8\end{array}$ \\
\hline 5. & $\begin{array}{l}\text { Dosage of Pesticides } \\
\text { a. Not according to label } \\
\text { b. As per the label }\end{array}$ & $\begin{array}{l}39 \\
41 \\
\end{array}$ & $\begin{array}{l}48,8 \\
51,3\end{array}$ \\
\hline
\end{tabular}

Relationship Between Work Period and Hemoglobin Level and the number of Erythrocytes Based on the results of the study in table 2, it shows that out of 67 respondents who have a working period of $>5$ years there are $55(82.1 \%)$ respondents who have abnormal hemoglobin, while from 13 respondents with a working period of $\leq 5$ years there are $4(30.8 \%)$ respondents who have abnormal hemoglobin. The results of the chi-square statistical test obtained a value of $p=0.001$, which means that there is a significant relationship between years of work with impaired hemoglobin levels in the District of Paal Merah, Jambi City.

Based on the results of the study in table 2, it shows that out of 67 respondents who have a working period of $>5$ years there are $13(23.9 \%)$ respondents who have an abnormal number of erythrocytes, while from 13 respondents with a working period of $\leq 5$ years there are $2(15.4 \%)$ respondents who have an abnormal number of erythrocytes. The chi-square statistic test results obtained $p$ value $=0.722$, which means there is no significant relationship between years of work with the number of erythrocytes in the Red Paal of Jambi City. 
[Nurhikmah et. al., Vol.6 (Iss.11): November 2018]

(Received: October 24, 2018 - Accepted: November 26, 2018)
ISSN- 2350-0530(O), ISSN- 2394-3629(P)

DOI: 10.5281/zenodo.1929368

\section{Relation of Frequency of Spraying with Hemoglobin Level and Number of Erythrocytes}

Based on the results of the study in table 2, it shows that from 57 respondents with the frequency of spraying> 2 times / week there were 46 (80.7\%) respondents who had abnormal hemoglobin, some of the 23 respondents with the frequency of spraying $\leq 2$ times / week there were as many as $13(56.5 \%)$ of respondents had abnormal hemoglobin. The results of the chi-square statistical test obtained a value of $\mathrm{p}=0.004$ which means there is a significant relationship between the frequency of spraying with hemoglobin levels in farmers in the District of Paal Merah, Jambi City. Based on the results of the study in table 2, it shows that of the 58 respondents with the frequency of spraying> 2 times / week there were $14(24.1 \%)$ respondents who had an abnormal number of erythrocytes, whereas from 22 respondents the frequency of spraying was 2 times / week 4 (18.2\%) respondents had abnormal erythrocytes. The chi-square statistic test results obtained $\mathrm{p}$ value $=$ 0.766 which means there is no significant relationship between the frequency of spraying with the number of erythrocytes in farmers in the District of Paal Merah, Jambi City.

\section{Relationship between Pesticide Doses and Hemoglobin Levels and the number of Erythrocytes}

Based on the results of the study in table 2, it shows that of the 40 respondents who used pesticide doses not in accordance with the label there were 35 (59.3\%) respondents who had abnormal hemoglobin levels, while from 40 respondents who used pesticide doses according to the label there were 24 (40,7\% of respondents who have abnormal hemoglobin levels. The results of the chi-square statistical test obtained a value of $p=0.011$, which means that there is a significant relationship between the dose of pesticides and hemoglobin levels in farmers in the District of Paal Merah, Jambi City.

Based on the results of the study in table 2, it shows that of the 30 respondents who used pesticide doses not in accordance with the label there were 5 (16.7\%) respondents who had an abnormal number of erythrocytes, while there were 13 respondents who used pesticide doses according to the label $(74,0 \%)$ respondents who have an abnormal number of erythrocytes. The chi-square statistical test results obtained $\mathrm{p}$ value $=0.479$ which means there is no significant relationship between the dose of pesticides and the number of erythrocytes of farmers in the District of Paal Merah, Jambi City.

\section{Discussion}

Relationship Between Work Period and Hemoglobin Level and the number of Erythrocytes Based on the results of statistical tests obtained $\mathrm{p}$ value $=0.001$, which means there is a significant relationship between years of work with hemoglobin levels on farmers. This is because most farmers have a working period of $>5$ years so that the longer the farmers spray, the longer the contact with pesticides will be, so the risk to health will be higher. Chronic exposure due to pesticides can produce changes in hematological parameters. The results of this study are in line with the results of a study conducted on 85 grape farmers who have been exposed to pesticides for 3 to 10 years also reported a decrease in hemoglobin levels with a value of $p=0.001$ (Patil, 2003). Based on the results of statistical tests obtained $p$ value $=0.722$, which means there is no significant relationship between work period with the number of erythrocytes in farmers in the District of Paal Merah, Jambi City. This study is in line with Rizqyana's (2017) study that the history of exposure did not have a significant relationship with the number of erythrocytes, $\mathrm{MCV}, \mathrm{MCH}(\mathrm{p}>0.05)$ 
(Rizqyana, 2017). This is due to the fact that the number of erythrocytes in general is still in a good category. In addition, if the hemoglobin level of the respondent is still above $8 \mathrm{~g} / \mathrm{dL}$, the average number of erythrocytes is still normal, and the other causes of decreased erythrocytes in the blood are bleeding or having a history of blood diseases such as leukemia (D'Hiru; 2013).

\section{Relation of Frequency of Spraying with Hemoglobin Level and Number of Erythrocytes}

Based on the results of the statistical test obtained the value of $p=0.004$ which means there is a significant relationship between the frequency of spraying with hemoglobin levels. Based on the results of the study that farmers sprayed $>2$ times / week so that too much contact with pesticides can affect the risk of hemoglobin levels becoming abnormal. This study is in line with Runia's (2008) study that sprayers who have $>5$ hours of work have a greater risk of pesticide poisoning than sprayers who have $<5$ hours of work hours (OR = 5.22) (Runia, 2008). It can be concluded that frequent spraying of pesticides will cause poisoning to farmers.

Based on the results of statistical tests obtained $p$ value $=0.766$ which means there is no significant relationship between the frequency of spraying with the number of erythrocytes in farmers in the District of Paal Merah, Jambi City. This study is in line with Rizqyana's (2017) study that the history of exposure did not have a significant relationship with the number of erythrocytes, MCV, $\mathrm{MCH}(\mathrm{p}>0.512)$ (Rizqyana, 2017).

\section{Relationship between Pesticide Doses and Hemoglobin Levels and the number of Erythrocytes}

Based on the results of the statistical test obtained the value of $p=0.011$, which means there is a significant relationship between the dose of pesticides with hemoglobin levels in farmers in the District of Paal Merah, Jambi City. In this study it was also found that farmers who did not mix the dosage according to the label had hemoglobin abnormally. In this study, farmers who carry out doses or doses that are not in accordance with the rules will result in increased construction and toxicity of pesticides. This research is in line with the research conducted by Marsaulina (2005) which shows that there is a relationship between the dose of pesticides against pesticide poisoning (Marsaulina, 2017).

Based on the results of statistical tests obtained $\mathrm{p}$ value $=0.355$ which means there is no significant relationship between pesticide doses and hemoglobin levels in farmers in the District of Paal Merah, Jambi City. This research is in line with the research conducted by Arwin (2016) which shows that there is no relationship between the dose of pesticides on the incidence of anemia (Arwin, 2016). 
Table 2: Results of statistical analysis of the relationship of independent variables with hemoglobin levels and erythrocyte counts in farmers in Paal Merah District in 2018

\begin{tabular}{|c|c|c|c|c|c|c|c|}
\hline \multirow[t]{2}{*}{ No } & \multirow[t]{2}{*}{ Variable } & \multicolumn{2}{|c|}{ Hemoglobin Levels } & \multirow[t]{2}{*}{$\begin{array}{c}p- \\
\text { value }\end{array}$} & \multicolumn{2}{|c|}{$\begin{array}{c}\text { Number Of } \\
\text { Erythrocytes }\end{array}$} & \multirow[t]{2}{*}{$\begin{array}{c}p- \\
\text { value }\end{array}$} \\
\hline & & Abnormal & Normal & & Abnormal & Normal & \\
\hline 1. & $\begin{array}{l}\text { Years of service } \\
>5 \text { years } \\
\leq 5 \text { years }\end{array}$ & $\begin{array}{l}55 \\
(82,1 \%)\end{array}$ & $\begin{array}{l}12 \\
(17,9 \%)\end{array}$ & $0,001 *$ & $\begin{array}{c}16(23,9 \%) \\
2(15,4 \%)\end{array}$ & $\begin{array}{l}51 \\
(76,1 \%) \\
11\end{array}$ & 0,722 \\
\hline 2. & $\begin{array}{l}\text { Frequency of } \\
\text { spraying }\end{array}$ & $4(30,8 \%)$ & $9(69,2 \%)$ & $0,004 *$ & $\begin{array}{c}14(24,1 \%) \\
4(18,2 \%)\end{array}$ & $(84,6 \%)$ & 0,766 \\
\hline 3. & $\begin{array}{l}>2 \text { times / week } \\
\leq 2 \text { times / week }\end{array}$ & $\begin{array}{l}46 \\
(80,7 \%)\end{array}$ & $\begin{array}{l}11 \\
(19,3 \%)\end{array}$ & & $11(28,2 \%)$ & $\begin{array}{l}44 \\
(75,9 \%)\end{array}$ & 0,645 \\
\hline & $\begin{array}{l}\text { Dosage of } \\
\text { Pesticides }\end{array}$ & 13 & 10 & $0,011 *$ & $7(17,1 \%)$ & 18 & \\
\hline & Not according to & & & & & & \\
\hline & label & & $5(23,8 \%)$ & & & 29 & \\
\hline & As per the label & $\begin{array}{l}(59,3 \%) \\
24 \\
(40,7 \%)\end{array}$ & $\begin{array}{l}16 \\
(76,2 \%)\end{array}$ & & & $\begin{array}{l}(72,5 \%) \\
33 \\
(82.5 \%)\end{array}$ & \\
\hline
\end{tabular}

\section{Conclusion}

This study concluded that there was a significant relationship between years of work with hemoglobin levels on farmers ( $\mathrm{p}$ value $=0.001$ ), there was a significant relationship between the frequency of spraying and hemoglobin levels ( $\mathrm{p}$ value $=0.004)$, there was a significant relationship between pesticide dosage levels hemoglobin in farmers (value $p=0.011$ ), There is no significant relationship between years of work with the number of erythrocytes in farmers ( $p$ value $=0.722$ ), there is no significant relationship between the frequency of spraying with the number of erythrocytes in farmers ( $\mathrm{p}$ value $=0.766$ ), there was no significant relationship between pesticide doses and hemoglobin levels in farmers ( $\mathrm{p}$ value $=0.645$ ).

This study suggests that farmers spray based on the recommended dosage of pesticides and also spray once a week so that they are not exposed to pesticides continuously which can lead to poisoning.

\section{References}

[1] Zamahsjari. Efektifitas Daya Lindung Pakaian Kerja Terhadap Keracunan Pestisida Pada Petani Tanaman Kedelai Jakarta: Pasca Sarjana Universitas Indonesia; 1994.

[2] Proverawati A. Anemia dan Anemia Kehamilan Nuha Medika. Yogyakarta; 2011.

[3] Subiyakto S. Pestisida. Yogyakarta: Penerbit Kanisius; 1991.

[4] Profil Dinas Kesehatan Kota Jambi Tahun 2016. Jambi: Dinas Kesehatan Kota Jambi; 2016.

[5] Patil JA, Govindwar SP. Biochemical Effects of Various Pesticides on Sprayers of Grape Gardens. Indian Journal of Clinical Biochemistry. 2003; 18(2): 16-22.

[6] Runia Y. Faktor-faktor yang berhubungan dengan keracunan pestisida organofosfat, karbamat dan kejadian anemia pada petani hortikultura di desa tejosari Kecamatan Ngablak Kabupaten Magelang. Jurnal Kesehatan Lingkungan Indonesia. 2008. 
[7] Sosan MB, Akingbohungbe AE, Durosinmi MA, Ojo IA. Erythrocyte Cholinesterase Enzyme Activity and Hemog;obin Values In cacao Farmers Of Southwestern Nigeria As Related To Insecticide Exposure. Archives of environmental \& occupational health. 2010;65(1):27-33.

[8] DPR I. Statistik Ketenagakerjaan Sektor Pertanian. Jakarta: Pusat Data dan Sistem Informasi Pertanian; 2013.

[9] Profil Badan Ketahanan Pangan dan Penyuluhan Kota Jambi Tahun 2016. Jambi: Badan Ketahanan Pangan dan Penyuluhan Kota Jambi; 2016.

[10] Rizqyana IF. Hubungan Riwayat Paparan Pestisida dengan Jumlah Eritrosit, MCV, MCH, MCHC, Pada Petani Sayuran di Desa Sumberejo Kecamatan Ngablak Kabupaten Magelang. Jurnal Kesehatan Masyarakat. 2017.

[11] Siswanto. Pestisida. Surabaya: Balai Hiperkes dan Ergonomi; 1991.

[12] Kusno. Pencegahan Pencemaran Pupuk dan Pestisida. Jakarta: Penebar Swadaya; 1989.

[13] Sofro AS. Darah. Yogyakarta: Pustaka Pelajar 2012.

[14] D’Hiru. Live Blood Analysis. Jakarta: Gramedia Pustaka Utama; 2013.

[15] Arwin NM. Pajanan Pestisida dan Kejadian Anemia Pada Petani Hortikultura di Kecamatan Cikajang, Kabupaten Garut tahun 2016. Journal of Community Medicine and Publict Health. 2016; $32(07)$.

[16] Marsaulina I. Faktor-Faktor Yang Berhubungan Dengan Keracunan Pestisida Pada Petani Hortikultura Di Kecamatan Jorlang Hataran Kabupaten Simalungun Tahin 2005. Jurnal Media Penelitian Dan Pengembangan Kesehatan. 2007;17.

\footnotetext{
*Corresponding author.

E-mail address: suheri.lpdp@ gmail.com
} 